\title{
Kynurenic acid enhances expression of p21 Waf1/Cip1 in colon cancer HT-29 cells
}

\author{
Katarzyna Walczak ${ }^{1,2}$, Waldemar A. Turski ${ }^{3,4}$, Wojciech Rzeski ${ }^{1,5}$ \\ ${ }^{1}$ Department of Medical Biology, Institute of Rural Health, Jaczewskiego 2, PL 20-950 Lublin, Poland \\ ${ }^{2}$ Department of Pharmacology, Medical University, Chodźki 4a, PL 20-093 Lublin, Poland \\ ${ }^{3}$ Department of Toxicology, Institute of Rural Health, Jaczewskiego 2, PL 20-950 Lublin, Poland \\ ${ }^{4}$ Department of Experimental and Clinical Pharmacology, Medical University, Jaczewskiego 8, PL 20-090 Lublin, \\ Poland \\ ${ }^{5}$ Department of Virology and Immunology, Institute of Microbiology and Biotechnology, Maria-Curie-Skłodowska \\ University, Akademicka 19, PL 20-033 Lublin, Poland
}

Correspondence: Katarzyna Walczak, e-mail: walczak.ka@gmail.com

\begin{abstract}
:
Background: Kynurenic acid (KYNA), a tryptophan metabolite, was found in the mucus of rat small intestine. However, its role in the gastrointestinal tract is still not fully elucidated.

Methods: To verify whether KYNA affects cell cycle regulators, the protein expression of cyclin-dependent kinase inhibitor p21 Waf1/Cip1 was investigated in colon adenocarcinoma HT-29 cells exposed to KYNA. MTT, BrdU assay and siRNA technology were used to evaluate the effect of KYNA on cancer cell proliferation.

Results: KYNA significantly enhanced the expression of p21 Waf1/Cip1. Importantly, the overexpression of this protein was involved in inhibition of proliferation and DNA synthesis in HT-29 cells.

Conclusions: KYNA may be considered as a potential chemoprevention agent against colon cancer.
\end{abstract}

Key words:

kynurenic acid, colon cancer, p21 Waf1/Cip1, proliferation

\begin{abstract}
Abbreviations: BrdU - 5'-bromo-2'-deoxy-uridine, CDK cyclin-dependent kinases, DMEM - Dulbecco's modified Eagle's medium, DTT - dithiothreitol, EDTA - ethylenediaminetetraacetic acid, EGTA - ethylene glycol tetraacetic acid, FBS fetal bovine serum, GPR - G-protein-coupled receptor, KYNA - kynurenic acid, MTT - 3-(4,5-dimethylthiazol-2-yl)-2,5diphenyltetrazolium bromide, PMSF - phenylmethanesulfonyl fluoride, PVDF - polyvinylidene fluoride, SDS - sodium dodecyl sulfate, SEM - standard error of the mean
\end{abstract}

\section{Introduction}

Kynurenic acid (KYNA), an endogenous metabolite of the kynurenine pathway of tryptophan degradation, is an agonist of orphan G-protein-coupled receptor (GPR35) which is predominantly expressed in immune and gastrointestinal tissues [24], a non-competi- 
tive antagonist of $\alpha 7$ nicotinic receptor and a broad spectrum antagonist of all types of ionotropic glutamate receptors $[8,20]$. Recently, it was also reported that KYNA is an agonist of aryl hydrocarbon receptor [2]. KYNA was found in human saliva [10], gastric juice, bile, pancreatic juice [15], mucus of rat small intestine [11] and mucus of pig colon [15]. Importantly, KYNA was also detected in several products of daily human diet and medicinal herbs [21, 22]. The highest concentration was reported in honeybee products and some fresh vegetables including broccoli and potato [22]. Although the role of KYNA in the gastrointestinal tract is still not fully elucidated, previous studies revealed its involvement in a complex duodenal mucosa protection system [5-7], modulation of intestinal motility, and inflammatory response in experimental colonic obstruction in dogs [9] and experimental colitis in rats [23]. Moreover, taking into consideration that KYNA supported the growth of probiotic bacteria in vitro, its potential role in the regulation of bacterial growth in the digestive system is suggested [3].

In this study, we report that KYNA significantly enhanced the expression of cell cycle regulator cyclin-dependent kinase (CDK) inhibitor p21 Waf1/ Cip1 in colon adenocarcinoma HT-29 cells. Moreover, KYNA-induced overexpression of p21 Waf1/ Cip1 was involved in inhibition of proliferation and DNA synthesis in HT-29 cells.

\section{Materials and Methods}

\section{Cell culture}

Colon adenocarcinoma HT-29 cells were obtained from ECACC (European Collection of Cell Cultures, Centre for Applied Microbiology and Research, Salisbury, UK). Cells were grown in 1:1 mixture of Dulbecco's modified Eagle's medium (DMEM) and nutrient mixture Ham F-12 supplemented with $10 \%$ fetal bovine serum (FBS), penicillin $(100 \mathrm{U} / \mathrm{ml})$ and streptomycin $(100 \mu \mathrm{g} / \mathrm{ml})$ and were maintained in a humidified atmosphere of $95 \%$ air and $5 \% \mathrm{CO}_{2}$ at $37^{\circ} \mathrm{C}$. All reagents were obtained from Sigma (Sigma Chemicals, St. Louis, MO, USA).

\section{MTT assay}

HT-29 cells were plated on 96-well microplates (Nunc, Roskilde, Denmark) at a density of $3 \times 10^{4}$ cells $/ \mathrm{ml}$. Next day, the culture medium was removed and the cells were exposed to serial dilutions of KYNA (0.00001-10 mM; Sigma) in a fresh medium and incubated for $48 \mathrm{~h}$. Cell proliferation was assessed by using the 3-(4,5-dimethylthiazol-2-yl)-2,5-diphenyltetrazolium bromide (MTT) method previously described by Rzeski et al. [19].

\section{BrdU assay}

HT-29 cells were plated on 96-well microplates (Nunc) at a density of $3 \times 10^{4}$ cells $/ \mathrm{ml}$. Next day, the culture medium was removed and the cells were exposed to serial dilutions of KYNA (0.00001-10 mM) in a fresh medium supplemented with $10 \% \mathrm{FBS}$ for $48 \mathrm{~h}$. The incorporation of 5'-bromo-2'-deoxyuridine (BrdU) into newly synthesised DNA of actively proliferating cells was measured by means of the BrdU method, previously described by Rzeski et al. [19].

\section{Gene silencing (siRNA)}

HT-29 cells were plated on 96-well microplates at a density of $3 \times 10^{4}$ cells $/ \mathrm{ml}$ the day before transfection with p21 siRNA (100 nM; Cell Signaling Technology Inc., Danvers, MA, USA). Transfection was carried out by using Lipofectamine 2000 (Invitrogen, Carlsbad, CA, USA). The following day, the cells were exposed to KYNA $(0.01,0.1$ and $1 \mathrm{mM})$ in a fresh medium for $48 \mathrm{~h}$. MTT assay was performed to evaluate cell proliferation. The p21 silencing was confirmed by western blot.

\section{Western blot analysis}

HT-29 cells were lysed in RIPA buffer (1\% NP40 (Tergitol), 0.5\% sodium deoxycholate, $0.1 \%$ SDS, $1 \mathrm{mM}$ EDTA, $1 \mathrm{mM}$ EGTA, $1 \mathrm{mM} \mathrm{Na} \mathrm{VO}_{4}, 20 \mathrm{mM}$ $\mathrm{NaF}, 0.5 \mathrm{mM}$ DTT, $1 \mathrm{mM}$ PMSF, protease inhibitor mixture in PBS, $\mathrm{pH} 7.4$ ) and centrifuged at 14,000 $\times \mathrm{g}$ for $10 \mathrm{~min}$. Protein content in supernatants was determined by BCA Protein Assay Kit (Pierce Biotechnology, Rockford, USA). Supernatants were solubilized in sample buffer (30\% glycerol, $10 \%$ SDS, $0.5 \mathrm{M}$ Tris-HCl, pH 6.8, 0.012\% bromophenol blue, 5\% $\beta$-mercaptoethanol), and boiled for $5 \mathrm{~min}$. For west- 
ern blotting, equal amounts of proteins were electrophoresed on $10 \%$ SDS-PAGE and transferred to PVDF membrane. After blocking for $1 \mathrm{~h}$ at room temperature with $5 \%$ non-fat dry milk in TBS- $0.1 \%$ Tween 20 (TBS-T), membranes were probed at $4{ }^{\circ} \mathrm{C}$ overnight with primary antibodies (p21 Waf1/Cip1 1:1000, $\beta$-actin 1:2000; Cell Signaling Technology). The membranes were then washed in TBS-T buffer and incubated with secondary antibody coupled to horseradish peroxidase (1:2000 in 5\% non-fat milk in TBS-T) for $1 \mathrm{~h}$ at room temperature and visualized by using enhanced chemiluminescence (Pierce Biotechnology). Serial exposures were made on Kodak BioMax Light film (Eastman Kodak Company, Rochester, New York, USA).

\section{Data analysis}

Data were presented as the mean value and standard error of the mean (SEM). Statistical analysis was performed using one-way ANOVA with Tukey post-hoc test; $\mathrm{p}<0.05$ was considered statistically significant. The $\mathrm{IC}_{50}$ value (the concentration of drug necessary to induce $50 \%$ inhibition), together with confidence limits, was calculated using computerized linear regression analysis of quantal log dose-probit functions, according to the method of Litchfield and Wilcoxon [12].

\section{Results and Discussion}

We report that KYNA significantly enhanced the expression of cell cycle regulator CDK inhibitor p21 Waf1/Cip1 in colon adenocarcinoma cells. HT-29 cells were exposed to $2.5 \mathrm{mM} \mathrm{KYNA}$ for $5 \mathrm{~min}-48 \mathrm{~h}$. Western blot analysis revealed that KYNA significantly increased protein levels of p21 Waf1/Cip1 starting at $4 \mathrm{~h}$ of exposition to tested compound (Fig. 1a). Interestingly, at $24 \mathrm{~h}$ of incubation with KYNA a considerable decrease of $\mathrm{p} 21 \mathrm{Waf1/Cip} 1$ expression was observed. Although the reason of this phenomenon is unknown, the significant differences in basal expression of $\mathrm{p} 21 \mathrm{Waf1} / \mathrm{Cip} 1$ in control cells (without KYNA) after 4 and $24 \mathrm{~h}$ of incubation may suggest that expression of this protein is dynamic through long-term experiment. Importantly, incubation with serial dilutions of KYNA $(0.01-5 \mathrm{mM})$ for 4,24 or $48 \mathrm{~h}$ revealed that the expression of $\mathrm{p} 21 \mathrm{Waf1} / \mathrm{Cip} 1$ a

KYNA $2.5 \mathrm{mM}$

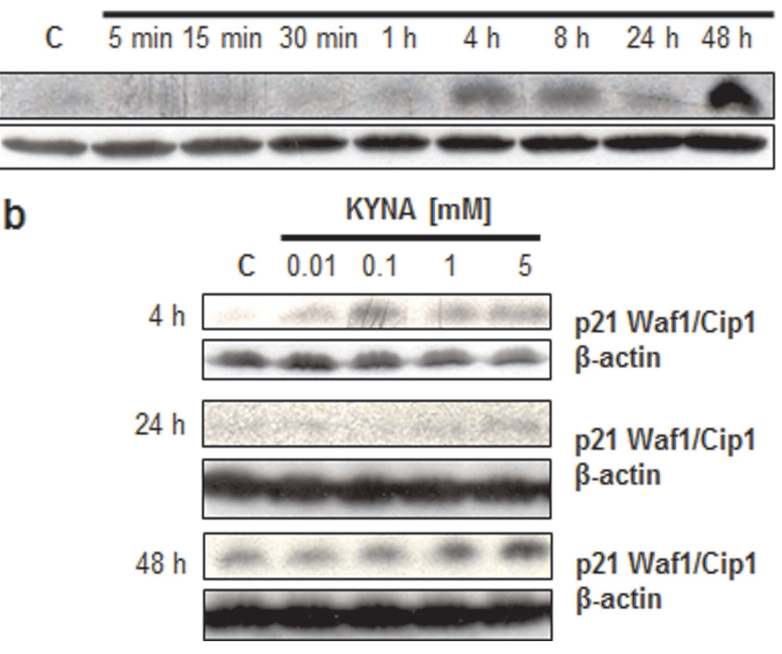

Fig. 1. Regulation of $p 21$ Waf1/Cip1 by KYNA. Western blot analysis of p21 Waf1/Cip1 in HT-29 cells after treatment with (a) KYNA $2.5 \mathrm{mM}$ for $5 \mathrm{~min}-48 \mathrm{~h}$, or (b) treatment with serial dilutions of KYNA $(0.01-5 \mathrm{mM})$ for 4,24 or $48 \mathrm{~h}$ (C - control; not treated)

was increased also in a dose-dependent manner (Fig. 1b). p21 Waf1/Cip1 is a cyclin-dependent kinase inhibitor involved in the regulation of cell cycle, apoptosis and cell differentiation [27]. In the intestinal tract, p21 Waf1/Cip1 is expressed in cells which exit the proliferative compartment, and disruption of this process may lead to carcinogenesis [17].

Although the preliminary character of this study do not allow to clearly specify the biological consequences of KYNA-induced overexpression of p21 Waf1/Cip1, our results suggested that enhanced expression of this protein may be involved in growth inhibition of colon adenocarcinoma HT-29 cells. We report that KYNA not only significantly inhibited proliferation of HT-29 cells (MTT assay; $\mathrm{IC}_{50}=2 \mathrm{mM}$ ) but also decreased DNA synthesis (BrdU assay; $\mathrm{IC}_{50}$ $=4.4 \mathrm{mM}$ ) after $48 \mathrm{~h}$ of incubation (Fig. 2a, 2b). A similar effect was previously reported in synoviocytes [16]. In contrast, Di Serio et al. [1] reported the stimulatory effect of KYNA on the proliferation rate of mouse microglia and human glioblastoma cells in vitro. Although we investigated the effect of KYNA in a broad range of concentrations from 0.00001 to $10 \mathrm{mM}$, we did not observe the stimulatory activity of KYNA in HT-29 cells. Importantly, the involvement of p21 Waf1/Cip1 in KYNA-induced growth inhibition of HT-29 cells was confirmed by means of gene silencing technology. We did not observe the antiprolifera- 


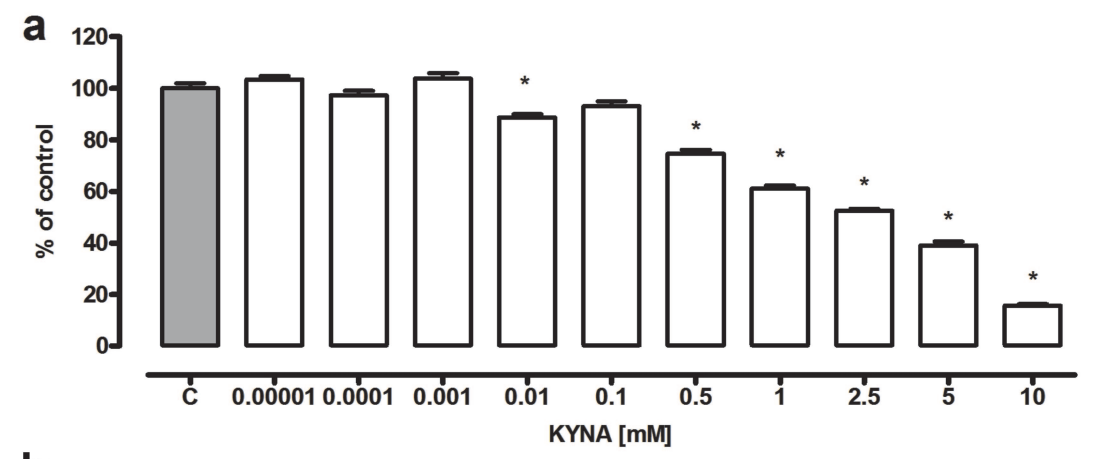

Fig. 2. The antiproliferative effect of KYNA on colon adenocarcinoma cells HT-29. Cells were exposed to fresh medium (control) or KYNA (0.00001$10 \mathrm{mM}$ ) for $48 \mathrm{~h}$. Proliferation was assessed by means of MTT assay (a) or BrdU assay (b). Data represent a mean value ( $\%$ of control) \pm SEM of six independent experiments. Values significant in comparison to control (100\%) with * $p<$ at least 0.05 (oneway ANOVA with Tukey post-hoc test). (c) Proliferation of HT-29 and HT-29 siRNA p21 Waf1/Cip1 cells after treatment with KYNA (0.01-1 mM) for $48 \mathrm{~h}$ (MTT assay, data represent a mean value (\% of control) \pm SEM of five independent experiments). (d) Confirmation of silencing p21 Waf1/Cip1 gene in HT-29 (western blot analysis); C control, p21 siRNA - cells with silenced p21 Waf1/Cip1 gen

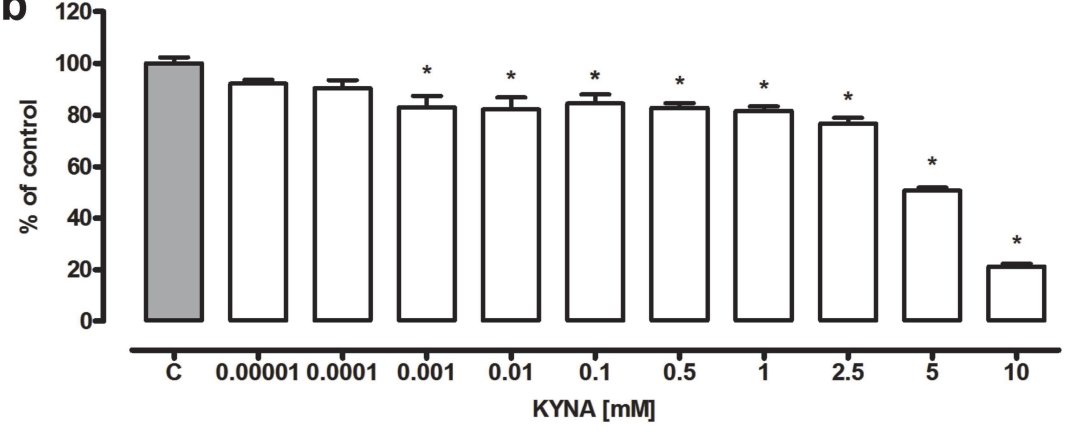

d

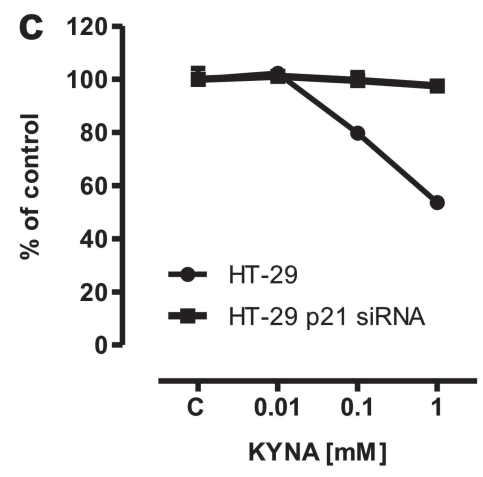

HT-29

HT-29 P21 siRNA

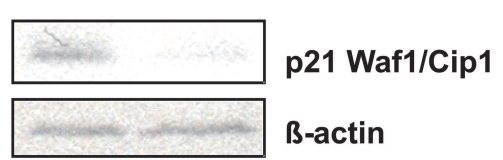

tive effect of KYNA in cells with silenced p21 Waf1/Cip1 gene (Fig. 2c, 2d). Our results are consistent with previous studies where Yamamoto et al. [26] revealed that overexpression of $\mathrm{p} 21$ Waf1/Cip1 in HT-29 cells is strongly associated with increased doubling time as well as decreased saturation density and plating efficiency. Moreover, p21 Waf1/Cip1, as an inhibitor of cell proliferation, plays an important role in drug-induced tumor suppression [13].

Since p21 Waf1/Cip1 is also involved in differentiation and apoptosis $[4,14,18,25]$, at this stage of our studies its role in those cellular processes in KYNA-treated HT-29 cells cannot be excluded. Several in vivo and in vitro experiments revealed that $\mathrm{p} 21$ Waf1/Cip1 expression is induced during terminal differentiation [14], however, this protein was also shown to decrease sodium butyrate-induced differen- tiation in HT-29 cells [26]. The role of p21 Waf1/Cip1 in apoptosis has not been unequivocally established. Generally, p21 Waf1/Cip1 protects cells from undergoing p53-mediated apoptosis [4]. However, previous studies indicated also that p21 Waf1/Cip1 in cells expressing mutated p53 may play a crucial role in promotion of apoptosis through a distinct apoptotic pathway $[18,25]$. Although it needs further investigations, KYNA-induced overexpression of p21 Waf1/Cip1 in HT-29 cells harboring mutated p53 may suggest its involvement in apoptosis in colon adenocarcinoma cells.

Nowadays, since colon cancer was emerged as a growing global health problem, the scientific effort is focused on designing the molecular targeted cancer therapies, significantly increasing the effectiveness of treatment. Taking into consideration antiproliferative activity, KYNA-induced overexpression of p21 Waf1/ 
Cip1 and long-term, multistep process of colon carcinogenesis, KYNA may be suggested as a novel chemopreventive agent against colon cancer. Interestingly, previous studies indicated that the loss of the p21 gene and Western-style diet were additive on colon tumor formation in the murine model [27]. It should be emphasized that KYNA content found in mucus of rat ileum $(0.003-0.016 \mathrm{mM})$ [11] and in mucus of pig colon $(\sim 0.0015 \mathrm{mM})$ [15] is high enough to influence expression of $\mathrm{p} 21 \mathrm{Waf1} / \mathrm{Cip} 1$ and proliferation of HT-29 cells in vitro. Importantly, KYNA concentration in gastrointestinal tract may be easily increased. Since KYNA is present in food [22] and medicinal herbs [21], it can be administered per $o s$ as a constituent of diet.

Although the specific biological consequences of enhanced expression of p21 Waf1/Cip1 in KYNAtreated HT-29 cells need further studies, its involvement in growth inhibition of colon adenocarcinoma cells suggested that KYNA may be considered as a potential chemoprevention agent against colon cancer.

\section{Acknowledgment:}

This study was supported in part by the Foundation for Polish Science.

\section{References:}

1. Di Serio C, Cozzi A, Angeli I, Doria L, Micucci I, Pellerito S, Mirone P et al.: Kynurenic acid inhibits the release of the neurotrophic fibroblast growth factor (FGF)-1 and enhances proliferation of glia cells, in vitro. Cell Mol Neurobiol, 2005, 25, 981-993.

2. DiNatale BC, Murray IA, Schroeder JC, Flaveny CA, Lahoti TS, Laurenzana EM, Omiecinski CJ, Perdew GH: Kynurenic acid is a potent endogenous aryl hydrocarbon receptor ligand that synergistically induces interleukin-6 in the presence of inflammatory signaling. Toxicol Sci, 2010, 115, 89-97.

3. Dolecka J, Urbanik-Sypniewska T, Skrzydło-Radomańska B, Parada-Turska J: Effect of kynurenic acid on the viability of probiotics in vitro. Pharmacol Rep, 2011, 63, 548-551.

4. Dotto GP: p21(WAF1/Cip1): more than a break to the cell cycle? Biochim Biophys Acta, 2000, 1471, M43-56.

5. Glavin GB, Bose R, Pinsky C: Kynurenic acid protects against gastroduodenal ulceration in mice injected with extracts from poisonous Atlantic shellfish. Prog Neuropsychopharmacol Biol Psychiatry, 1989, 13, 569-572.

6. Glavin GB, Pinsky C: Kynurenic acid attenuates experimental ulcer formation and basal gastric acid secretion in rats. Res Commun Chem Pathol Pharmacol, 1989, 64, 111-119.
7. Glavin GB, Pinsky C, Bose R: Gastrointestinal effects of contaminated mussels and putative antidotes thereof. Canad Dis Wkly Rep, 1990, 16, 111-115.

8. Hilmas C, Pereira EF, Alkondon M, Rassoulpour A, Schwarcz R, Albuquerque EX: The brain metabolite kynurenic acid inhibits $\alpha 7$ nicotinic receptor activity and increases non- $\alpha 7$ nicotinic receptor expression: physiopathological implications. J Neurosci, 2001, 21, 7463-7473.

9. Kaszaki J, Palasthy Z, Erczes D, Racz A, Torday C, Varga G, Vécsei L, Boros M: Kynurenic acid inhibits intestinal hypermotility and xanthine oxidase activity during experimental colon obstruction in dogs. Neurogastroenterol Motil, 2008, 20, 53-62.

10. Kuc D, Rahnama M, Tomaszewski T, Rzeski W, Wejksza K, Urbanik-Sypniewska T, Parada-Turska J et al.: Kynurenic acid in human saliva - does it influence oral microflora? Pharmacol Rep, 2006, 58, 393-398.

11. Kuc D, Zgrajka W, Parada-Turska J, Urbanik-Sypniewska T, Turski WA: Micromolar concentration of kynurenic acid in rat small intestine. Amino Acids, 2008, 35, 503-505.

12. Litchfield JT, Wilcoxon FA: A simplified method of evaluating dose-effect experiments. J Pharmacol Exp Ther, 1949, 96, 99-113.

13. Liu S, Bishop WR, Liu M: Differential effects of cell cycle regulatory protein $\mathrm{p} 21$ (WAF1/Cip1) on apoptosis and sensitivity to cancer chemotherapy. Drug Resist, 2003, 6, 183-195.

14. Missero C, Calautti E, Eckner R, Chin J, Tsai LH, Livingston DM, Dotto GP: Involvement of the cell-cycle inhibitor Cip1/WAF1 and the E1A-associated p300 protein in terminal differentiation. Proc Natl Acad Sci USA, 1995, 92, 5451-5455.

15. Paluszkiewicz P, Zgrajka W, Saran T, Schabowski J, Piedra JL, Fedkiv O, Rengman S et al.: High concentration of kynurenic acid in bile and pancreatic juice. Amino Acids, 2009, 37, 637-641.

16. Parada-Turska J, Rzeski W, Zgrajka W, Majdan M, Kandefer-Szerszeń M, Turski W: Kynurenic acid, an endogenous constituent of rheumatoid arthritis synovial fluid, inhibits proliferation of synoviocytes in vitro. Rheumatol Int, 2006, 26, 422-426.

17. Polyak K, Hamilton SR, Vogelstein B, Kinzler KW: Early alteration of cell-cycle-regulated gene expression in colorectal neoplasia. Am J Pathol, 1996, 149, 381-387.

18. Ramondetta L, Mills GB, Burke TW, Wolf JK: Adenovirus-mediated expression of p53 or p21 in a papillary serous endometrial carcinoma cell line (SPEC-2) results in both growth inhibition and apoptotic cell death: potential application of gene therapy to endometrial cancer. Clin Cancer Res, 2000, 6, 278-284.

19. Rzeski W, Turski L, Ikonomidou C: Glutamate antagonists limit tumor growth. Proc Natl Acad Sci USA, 2001, 98, 6372-6377.

20. Schwarcz R, Pellicciari R: Manipulation of brain kynurenines: glial targets, neuronal effects, and clinical opportunities. J Pharmacol Exp Ther, 2002, 303, 1-10.

21. Turski MP, Turska M, Zgrajka W, Bartnik M, Kocki T, Turski WA: Distribution, synthesis, and absorption of kynurenic acid in plants. Planta Med, 2011, 77, 858-864. 
22. Turski MP, Turska M, Zgrajka W, Kuc D, Turski WA: Presence of kynurenic acid in food and honeybee products. Amino Acids, 2009, 36, 75-80.

23. Varga G, Erces D, Fazekas B, Fülöp M, Kovács T, Kaszaki J, Fülöp F et al.: N-Methyl-D-aspartate receptor antagonism decreases motility and inflammatory activation in the early phase of acute experimental colitis in the rat. Neurogastroenterol Motil, 2010, 22, 217-225.

24. Wang J, Simonavicius N, Wu X, Swaminath G, Reagan J, Tian H, Ling L: Kynurenic acid as a ligand for orphan G protein-coupled receptor GPR35. J Biol Chem, 2006, 281, 22021-22028.

25. Wu Q, Kirschmeier P, Hockenberry T, Yang TY, Brassard DL, Wang L, McClanahan T, Black S et al.: Transcriptional regulation during $\mathrm{p} 21 \mathrm{WAF} 1 / \mathrm{CIP} 1$-induced apoptosis in human ovarian cancer cells. J Biol Chem, 2002, 277, 36329-36337.
26. Yamamoto H, Soh JW, Shirin H, Xing WQ, Lim JT, Yao Y, Slosberg E et al.: Comparative effects of overexpression of p27Kip1 and p21Cip1/Wafl on growth and differentiation in human colon carcinoma cells. Oncogene, 1999, 18, 103-115.

27. Yang WC, Mathew J, Velcich A, Edelmann W, Kucherlapati R, Lipkin M, Yang K, Augenlicht LH: Targeted inactivation of the p21(WAF1/cip1) gene enhances Apcinitiated tumor formation and the tumor-promoting activity of a Western-style high-risk diet by altering cell maturation in the intestinal mucosal. Cancer Res, 2001, $61,565-569$.

Received: July 4, 2011; accepted: December 13, 2011. 